\title{
$\mathrm{cN} 2 \mathrm{pN} 0$ 症例48例についての検討
}

\section{Computed Tomographic Evaluation of False Positive Cases of Lymph Node Metastasis from Primary Lung Cancer}

瀬戸眞由美 $^{1,2} \cdot$ 栗山啓子 $^{2} \cdot$ 横内秀起 $^{3} \cdot$ 木戸尚治 ${ }^{2} \cdot$ 東山聖彦 $^{3}$

児玉 憲 ${ }^{3} \cdot$ 瀬戸貴司 $^{4,5} \cdot$ 宝来 威 $^{4} \cdot$ 黒田知純 $^{2}$

\begin{abstract}
要旨：1988年から1996年まで当センターで外科的切除された原発性肺癌731症例について, N因 子診断の正診率は $66.3 \%$ てったた。のうち, 術前CTにおいて綐隔リンパ節に短径 $10 \mathrm{~mm}$ 以上の腫大を認め, 転移陽性と判断した原発性肺癌症例のうち, 術後診断で転移を認め なかった, いわゆる $\mathrm{cN} 2 \mathrm{pN} 067$ 症例中, 当センターで術前CTを施行した48症例について 検討を行った.false positiveのリンパ節の組織学的所見はリンパ瀘胞の発達したものが 殆どであったが，サルコイド様反応を呈した症例も認めた。組織型や腫大リンパ節の部 位, 原発巣の部位などでの有意な傾向は認めなかったが，48例中29例に何らかの他病変 が指摘可能であった. 正しいN因子の診断は, 適切な治療や正確な予後判定に不可欠であ り, 特に手術適応症例においてはMRIや超音波気管支内視鏡, 縱隔鏡を用いた生検など を含めた正確な診断が必要と考えられた。
\end{abstract}

〔肺癌 39(4)：403〜409, 1999〕

Key words : Lung cancer, Computed tomography, Mediastinal lymph node, Lymph node metastasis

\section{1.はじめに}

肺癌のTNM分類は, その治療法の選択にあた り,きわめて重要であり, とくに縦隔リンパ節 転移の有無は，予後に与える影響が大きいため に,治療前にN因子を正確に診断することは重要 である. 現在, N因子評価の標準モダリティは造 影CTで, 短径 $10 \mathrm{~mm}$ を越えるリンパ節を転移陽 性とするという診断基準が一般的である。この 診断基準を用いた報告での正診率は60〜80\% と

1. 現 瀬戸病院内科

2. 大阪府立成人病センター放射線診断科

3. 同胸部外科

4. 同 第 4 内科

5. 現 熊本地域医療センター呼吸器科
するものが大部分であるが ${ }^{1) 31}$, 最近は60\%をや や越える程度の比較的低い診断率のものが目だ っている4). 当センターに拈いても，1988年から 1996年までのあいだに行った原発性肺癌731例に おける正診率は $66.3 \%$ あっむた。

今回我々は, 術前CTで縦隔リンパ節転移陽性 と判定しながら, 病理学的に癌細胞を認めなか ったいわゆる $\mathrm{CN} 2 \mathrm{pN} 0$ 症例のCT画像につき検 討したので，文献的考察を加え，報告する．

\section{2. 対象と方法}

対象は，1988年から1996年までに大阪府立成 人病センターにおいて術前に造影 CTを施行し, その後外科切除された原発性肺癌のうち, 術前 
Table 1. Patient characteristics.

\begin{tabular}{ll}
\hline Male/Female & $37 / 11$ \\
Age & $37-79$ (median 66) \\
Squamous cell carcinoma & 18 \\
Adenocarcinoma & 24 \\
Small cell carcinoma & 3 \\
Large cell carcinoma & 3 \\
\hline
\end{tabular}

Table 2. $\mathrm{cN}$ versus $\mathrm{pN}$.

\begin{tabular}{crrrrr}
\hline & pN0 & pN1 & pN2 & pN3 & Total \\
\hline $\mathrm{cN} 0$ & 372 & 60 & 47 & 0 & 479 \\
$\mathrm{cN} 1$ & 12 & 29 & 15 & 2 & 58 \\
$\mathrm{cN} 2$ & 67 & 24 & 81 & 9 & 181 \\
$\mathrm{cN} 3$ & 4 & 2 & 4 & 3 & 13 \\
\hline Total & 455 & 115 & 147 & 14 & 731 \\
\hline
\end{tabular}

\begin{tabular}{ll}
\hline cN accuracy & $66.3 \%$ \\
cN3 sensitivity & $21.4 \%$ \\
cN3 specificity & $92.9 \%$ \\
cN3 accuracy & $97.1 \%$ \\
cN2 sensitivity & $55.1 \%$ \\
cN2 specificity & $81.2 \%$ \\
cN2 accuracy & $77.3 \%$ \\
\hline
\end{tabular}

診断 $\mathrm{N} 2$ 術後病理診断 $\mathrm{N} 0(\mathrm{cN} 2 \mathrm{pN} 0)$ であった 48 症例である。男性 37例, 女性 11例で, 年齢は 37才から79才, 平均值は64.4才であった. 扁平 上皮癌 18例, 腺癌 24 例, 小細胞癌 3 例, 大細 胞癌 3 例であった (Table 1).

使用したCT機種はシーメンス製SOMATOM PLUSおよび東芝製TCT-900Sであった.スライ ス幅 $5 \mathrm{~mm}$ で, 画像の描出条件はウィンドウ幅 300HU，ウィンドウレベル 50HUで撮像した. リンパ節転移陽性の診断基準は腫大リンパ節が 最大径を呈するスライスで短径 $10 \mathrm{~mm}$ 以上とした. 原発巣について, そのサイズ, 部位, リンパ節 について, サイズ, 部位, 組織所見を検討した. その他, 原発巣以外の随伴病変の有無について 検討した。

\section{3. 結 果}

臨床病期分類と病理病期分類におけるN因子診
Fig. 1. Case 1: A 67-year-old man with squamous cell carcinoma.

a) Chest CT scan shows a $38 \times 30 \mathrm{~mm}$ mass located in right S10.

b) Enhanced CT images obtained with standard mediastinal windows indicates enlarged mediastinal lymph nodes.

c) Histopathological findings of enlarged lymph nodes show follicular hyperplasia and no cancer metastasis.

a)

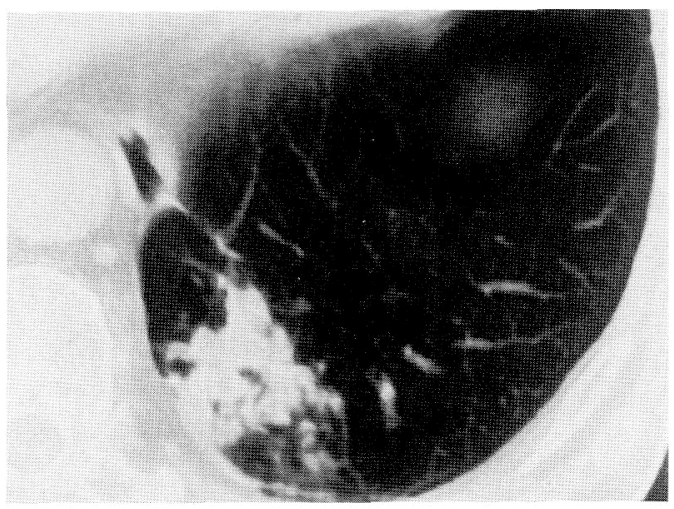

b)

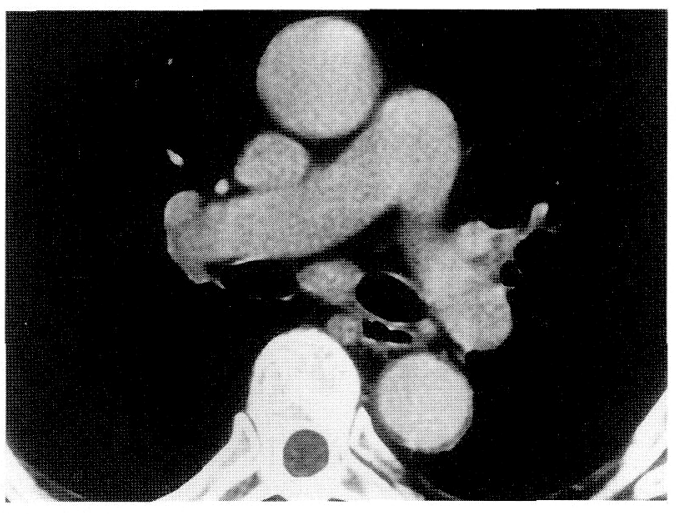

c)

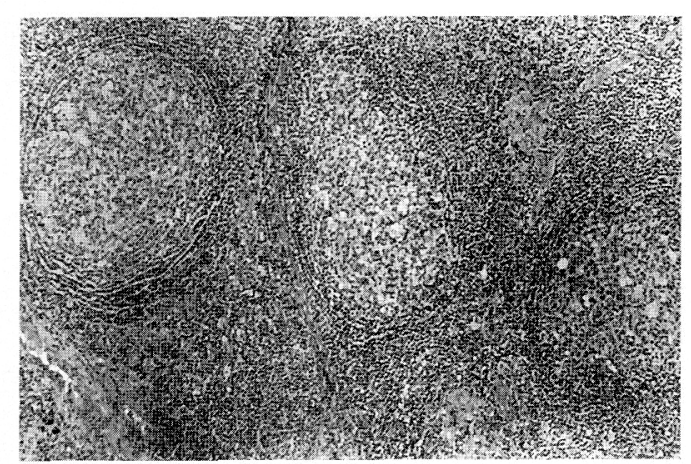

断の結果は, Table 2に示す如くであった. N因 子の正診率恃全体で $66.3 \%$ であた。

false positiveのリンパ節における組織学的所 
Fig. 2. Case 2: A 73-year-old man with squamous cell carcinoma.

a) Chest CT scan shows a $15 \times 15 \mathrm{~mm}$ mass located in right S4.

b) Enhanced CT images obtained with standard mediastinal windows indicate enlarged mediastinal lymph nodes.

c) Histopathological findings of the lymph nodes show non-caseating epithelial cell granulomas with giant cell and no cancer metastasis.

a)

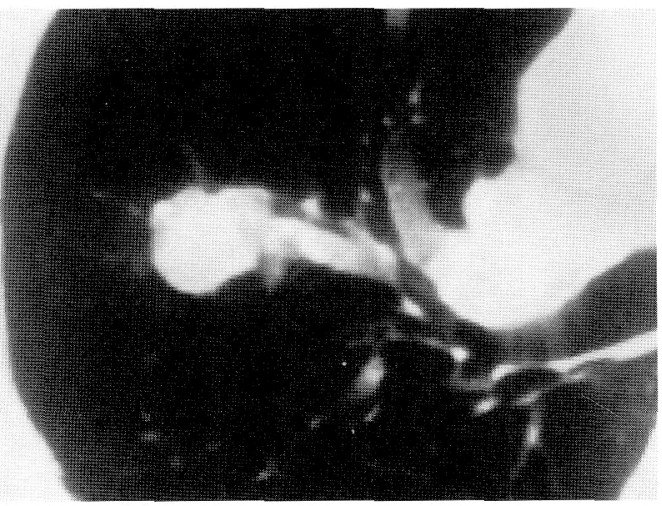

b)

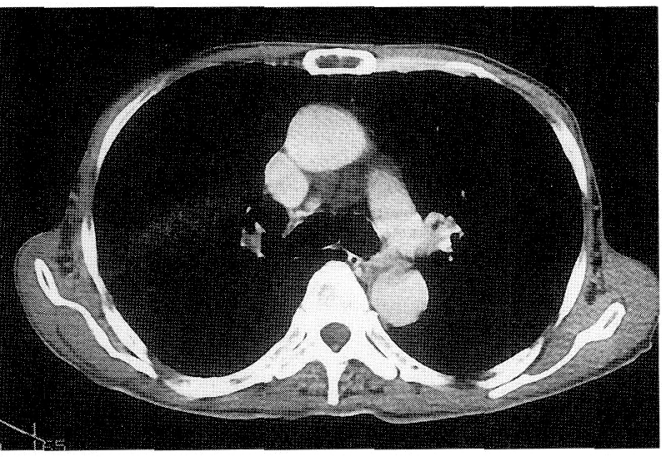

c)

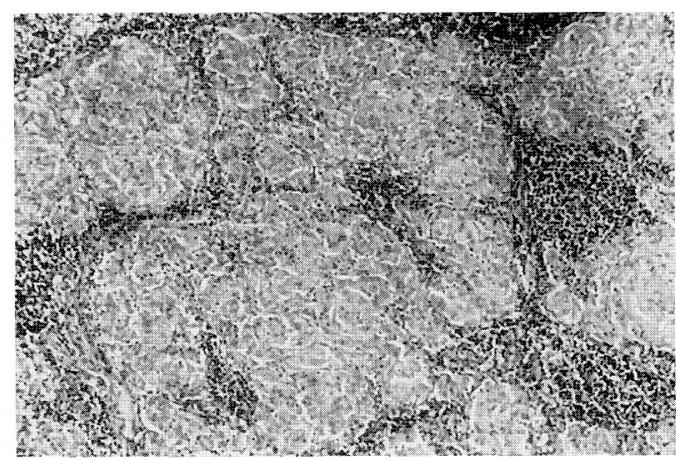

見は，リンパ瀘胞の発達したものが殆どであっ たが，非乾酪性類上皮細胞性肉芽を呈する，い わゆるサルコイド様反応と診断されたものが 5 症例みられた。
Fig. 3. Site of mediastinal lymph nodes and histological type of primary lesions in cases which were diagnosed by CT.

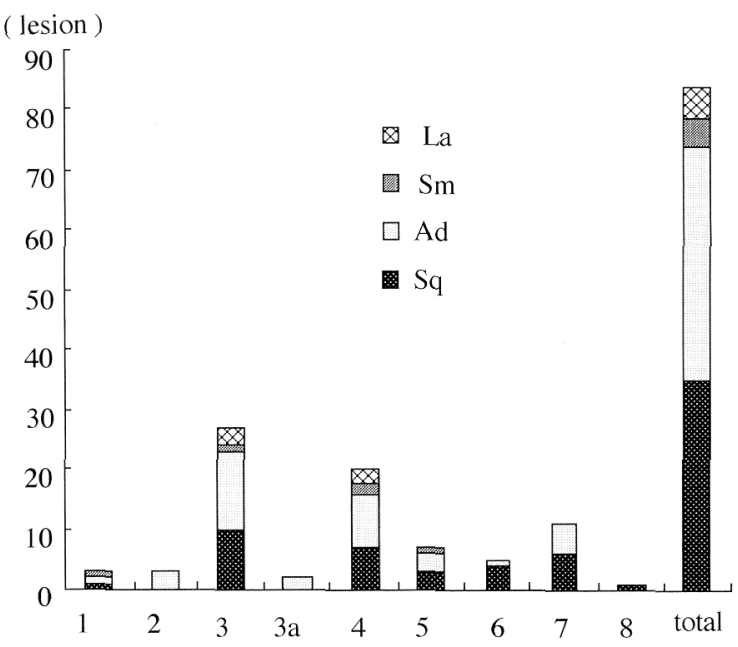

\section{1 )症例提示}

症例 1 : 67才男性, 扁平上皮癌の症例で, 左 $\mathrm{S} 10$ に $38 \times 30 \mathrm{~mm}$ の原発巣を認める (Fig. 1a).造 影CTの縦隔条件において, Fig. 1bに示守如く, 7 番に短径 $10 \mathrm{~mm}$ を越えるリンパ節腫大を認めた. また図には示していないが，4番リンパ節にも 腫大を認めた。切除標本HE像では, リンパ瀘胞 の発達を認めるのみで，癌細胞の転移は認めな かった (Fig. 1c).

症例 $2 ： 73$ 才男性, 扁平上皮癌の症例で, 右 $\mathrm{S} 4$ に $15 \times 15 \mathrm{~mm}$ の原発巣を認める(Fig. 2a)。造 影 CT縦隔条件に扮いて, 3 番リンパ節の腫大を 認める (Fig. 2b). HE標本でみると, 著明な組織 球の増生を認め, サルコイド椂反忘による腫大 と判断した。癌細胞の転移は認められなかった (Fig. 2c).

2 )cN2pNO症例の組織型 (Fig. 3)

造影CT縦隔条件に捛いて, 指摘した短径 $10 \mathrm{~mm}$ 以上のリンパ節は総計で79病変であった。この リンパ節について，組織型との関連をみたが， 扁平上皮癌 32 病変, 腺癌 37 病変, 小細胞癌 5 病変，大細胞癌 5 病変であった。症例数の比較 的多かった扁平上皮癌, 腺癌について, そのリ ンパ節の短径は, 扁平上皮癌が $10.438 \pm 0.840 \mathrm{~mm}$, 腺癌が $10.378 \pm 1.120 \mathrm{~mm}$ であり, 統計学的な有 
Fig. 4. Site and size of mediastinal lymph nodes in cases which were diagnosed by CT.

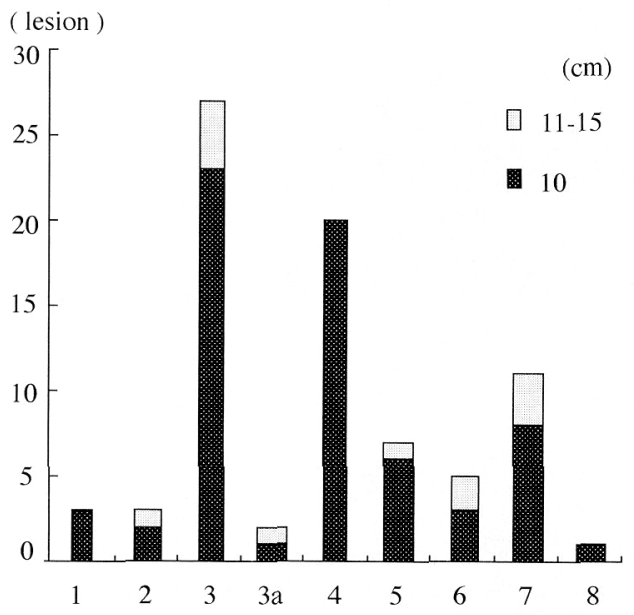

Fig. 6. Size of primary lesions and site of mediastinal lymph nodes which were diagnosed by CT.

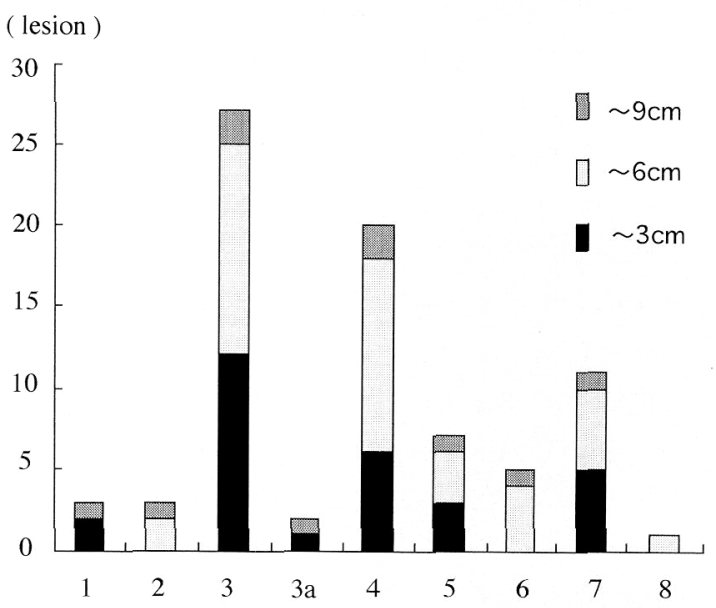

Fig. 5. Site of primary lesions and mediastinal lymph nodes in cases which were diagnosed by CT.

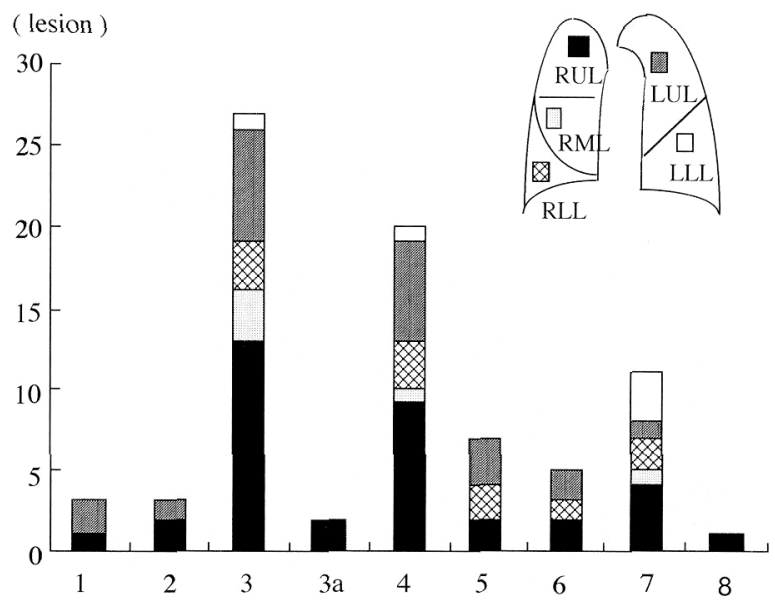

意差淂られなかった。

3 ) cN2pNO症例の部位 (Fig. 4)

気管前リンパ節 ( 3 番)，気管気管支リンパ節 ( 4 番)，気管分岐部リンパ節 ( 7 番) に多く認め られたが,そのサイズは79病変中 67 病変 $(84.8 \%)$ が短径 $10 \mathrm{~mm}$ として指摘したものであり, $16 \mathrm{~mm}$ 以上のリンパ節は認められなかった。

4 ) 原発巣の部位・大きさとリンパ節腫脹の関連 (Fig. 5, 6)

原発巣の部位やサイズとの間に，有意な傾向 は得られなかった。なお，腫脹を認めた気管気 管支リンパ節 ( 4 番)については，すべて原発巣 と同側であった。

5 )他病変の有無 (Table 3)

随伴病変の有無については, 48例中29例 (60.4

Table 3. Other pulmonary lesion accompanying primary lung cancer $(n=29)$.

\begin{tabular}{lccccc}
\hline & $\mathrm{SQ}$ & $\mathrm{AD}$ & $\mathrm{SM}$ & $\mathrm{LA}$ & Total \\
\hline $\begin{array}{l}\text { postinflamatory change } \\
\text { Or calcified nodule }\end{array}$ & 6 & 6 & 3 & 1 & 16 \\
atelectasis or secondary change & 3 & 4 & 0 & 0 & 7 \\
bulla & 1 & 4 & 0 & 0 & 5 \\
COPD & 3 & 1 & 0 & 0 & 4 \\
\hline Total & 13 & 15 & 3 & 1 & 32 \\
\hline
\end{tabular}

$\mathrm{SQ}$ : squamous cell carcinoma, $\mathrm{AD}$ : adenocarcinoma, SM : small cell carcinoma, LA : large cell carcinoma 
\%)について,なんらかの他病変が指摘可能であ った。炎症後変化および石灰化結節16例, 末梢 無気肺および二次変化 7 例, ブラ 5 例, $\mathrm{COPD}$ 4 例であった。

\section{4. 考 察}

縦隔リンパ節転移の有無は, 肺癌の予後や治 療法の選択を左右する重要な因子である ${ }^{5), 6)}$. 本 邦では, 非侵襲的であり, 空間分解能に優れる といら理由から, CTが汎用され, その診断基準 や有用性について,多くの報告がなされてきた. しかし, 現在の大きさによるリンパ節転移の基 準では, リンパ節腫大と癌転移が必ずしも一致 せず, CTによるN因子の正診率は60～80\%であ る.これについて, 西山らは, 1 ) 何 $\mathrm{cm}$ 以上のリ ンパ節腫大を異常ととるか, 2 ) 縦隔リンパ節の 各位置のCTによる描出能の違い, 3 ) 肺癌の組 織型による差を問題点として挙げている ${ }^{2)}$.

今回の我々の検討において, 非転移リンパ節 腫大の部位は気管前リンパ節, 気管気管支リン パ節，気管分岐部リンパ節が多かったが，その サイズは短径 $10 \mathrm{~mm}$ ののが79病変中 67 病変と最 も多かった。藤本らは気管分岐部リンパ節に関 しては, 非転移リンパ節の短径の最大值は $12 \mathrm{~mm}$ であったと述べており ${ }^{7)}$ ，をた池添らは，気管分 岐部, 気管前, 気管気管支リンパ節に関しては, 転移陽性の診断基準を $13 \mathrm{~mm}$ とすれば偽陽性が減 少すると述べている ${ }^{8)}$. 鈴木らは短径 $10 \mathrm{~mm}$ 以上, 気管分岐部リンパ節についてのみ $15 \mathrm{~mm}$ 以上を転 移陽性とする診断基準を採用した ${ }^{9)}$ が, 今回の検 討に掠いて, 短径 $16 \mathrm{~mm}$ 以上の非転移リンパ節腫 大は認められず, また, 短径 $11 \mathrm{~mm}$ 以上であった 非転移リンパ節12病変のらち, 気管分岐部リン パ節が 3 病変, 気管前リンパ節が 4 病変であつ たことから，部位別による診断基準設定を設け ることによって,false positiveが減少すると考 えられた。

また, 組織型によるリンパ節腫大の差につい て，今回の検討においては, 非転移リンパ節の 大きさについては統計学的な有意差は得られず, 従来いわれているような腺癌の転移リンパ節は 扁平上皮癌のそれより有意に小さく, 扁平上皮
癌では他の組織型と比較して偽陽性が多い(4),8) と いう結果は得られなかった。 また，従来の腺癌 の転移リンパ節が扁平上皮癌に比べて有意に小 さいと言われていることについても, 組織型に よって転移陽性の診断基準を $10 \mathrm{~mm}$ 以下にすると いうことは実用的ではなく, リンパ節の大きさ のみで診断基準を用いることに限界があると考 えられる.48症例中 29 症例 (60.4\%) については 何らかの随伴病変を認めた。慢性の気管支病変 や随伴する二次変化のため, リンパ節の炎症性 腫大や肉芽腫性腫大が認められることは, 以前 より指摘されていたが4), false positiveとなる 一因と考えられた。しかし，これについても， 二次変化の有無によって診断基準值を変更する ことは実際的ではない.

今後, N因子の正診率向上のためには, 腫大し た非転移リンパ節や腫大を認めない転移リンパ 節の診断の向上を図る必要がある。また, 田内 らは, リンパ節転移の際に, CT所見上, 辺縁不 整, 他臓器浸潤などの被膜外浸潤についての重 要性を報告している ${ }^{10)}$ が, リンパ節転移の有無 について, 大きさだけでなく, その内部構造や 辺縁のCT上での所見を用いた検討による正診率 向上の可能性も残されており, CTのみでなく, MRIや縦隔鏡, 気管支超音波内視鏡などの各種 モダリティの検討，あるいは開胸生検の必要性 の検討を行う必要があると考えられた。

\section{5. 結 語}

臨床病期分類 $\mathrm{N} 2$, 病理病期分類N0であった 48 症例について検討した。非転移リンパ節の短径 は10〜 15mmまでであったが, 組織型による短径 の有意差は認めなかった. 気管前, 気管気管支, 気管分岐部リンパ節に非転移リンパ節が多く認 められ, 部位別の診断基準を設けることで偽陽性 が減少すると考えられた. 副病変の存在も偽陽性 の一因と考えられた.リンパ節の大きさのみを 転移の診断基淮に用いることは限界があり, 各 種モダリティの導入を含めた検討が必要である.

本論文の要旨は第38回日本肺癌学会総会(仙台)において 発表した。 
1）前原康延, 松本満臣, 野崎美和子, 他：原発性 肺癌の術前臨床病期分類におけるCTの有用性に ついての評価. 肺癌 $25: 581-588,1985$.

2) 西山祥行, 梶田正文, 矢野平一, 他: CTによる 肺癌縦隔リンパ節転移の診断一肺癌切除63例を 中心に一. 肺癌 $25: 977-985,1985$.

3）稲岡正己, 庭瀬公武, 草島勝之, 他 : 肺癌にお けるClinical, Surgical, Pathological TNMの 比較検討. 肺癌 $21: 289-293,1981$.

4) 楠本昌彦, 足立秀治, 河野通雄 : 臨床画像, 癌 リンパ節転移の画像診断一可能性と限界. 肺癌 編集, 平松慶博, MEDICAL VIEW, 東京, 5667頁, 1994.

5) Martini N, Flehinger BJ, Ravin CE, et al : Prospective study of 445 lung carcinomas with mediastinal lymphnode metastasis. J Thorac Surg $80: 390-399,1980$.

6）小林英夫, 松岡緑郎, 北村 諭, 他：肺癌の縦
隔リンパ節に対する, CTによる診断基準につい て. 肺癌 $28: 731-737,1988$.

7) Ikezoe J, Kadowaki K, Morimoto S, et al : Mediastinal Lymph node metastasis from non-small cell bronchogenic carcinoma: revaluation with CT. J Comput assit Tomogr $14: 340-344,1990$.

8）藤本公則：縦隔リンパ節転移診断における基礎 的研究一非小細胞肺癌患者の摘出リンパ節の非 転移, 転移リンパ節径の比較一. 肺癌 $33: 533-$ 542, 1993.

9) 鈴木正行 : 原発性肺癌の縦隔リンパ節転移のCT 診断に関する基礎的ならびに臨床的検討. 日本 医放会誌 $48: 308-327,1988$.

10）田内扸泰, 渡辺賢一, 河野通雄, 他: 縦隔リン パ節転移のCT像の検討－ extranodalおよび intranodal involvmentの所見について.リンパ 学 $8: 139-142,1985$. 


\title{
Computed Tomographic Evaluation of False Positive Cases of Lymph Node Metastasis from Primary Lung Cancer
}

\author{
Mayumi Seto ${ }^{1,2}$, Keiko Kuriyama ${ }^{2}$, Hideoki Yokouchi ${ }^{3}$ \\ Shoji Kido', Masahiko Higashiyama ${ }^{3}$, Ken Kodama ${ }^{3}$ \\ Takashi Seto ${ }^{4,5}$, Takeshi Horai ${ }^{4}$ \\ and Chikazumi Kuroda ${ }^{2}$
}

1) Division of Internal Medicine, Seto Hospital

2) Department of Diagnostic Radiology

3) Department of Thoracic Surgery and

4) Fourth Department of Internal Medicine,

Osaka Medical Center for Cancer and Cardiovascular Diseases

5) Division of Respiratory Diseases, Kumamoto Regional Medical Center

In patients with surgically resected primary lung cancers, the thoracic CT findings suggesting a diagnosis of metastasis in mediastinal lymph nodes were compared with postoperative histological finding.

There were 48 false positive cases. The ages ranged from 37 to 79 , and 37 were men. In comparison of clinical $\mathrm{N}$ and pathological $\mathrm{N}$, accuracy of the former in relation to based on pathological $\mathrm{N}$ was $66.3 \%$. Our results suggested no difference in histological type, size and location of the primary tumor or location of the enlarged lymph nodes. However, in 29 of the 48 patients, there were other lesions, such as postinflamatory changes, calcified nodules or bullae. Assumption of metastasis disease can lead to inaccurate staging of the disease and inaccurate treatment and prognosis of the patients. Analysis of a larger series is needed. Furthermore, in operable cases, other modalities such as MRI, endobronchial ultrasound, and mediastinoscopic biopsy should be performed to adequately exclude metastatic disease. 